\title{
Predmet a rozsah dokazovania insolvenčných trestných činov ${ }^{1}$
}

\author{
Eduard Burda* \\ DOI: https://doi.org/10.24040/sap.2021.8.2-3.121-133
}

\begin{abstract}
Abstrakt:
BURDA, Eduard: Predmet a rozsah dokazovania insolvenčných trestných činov. Predmetný vedecký článok analyzuje legálnu definíciu predmetu dokazovania $\mathrm{v}$ trestnom konaní, vrátane stanovenia, ktoré skutočnosti iba treba dokazovat' a ktoré sa dokázat' musia a rieši špecifiká predmetu a rozsahu dokazovania insolvenčných trestných činov. Vedecký článok z tohto hl'adiska prináša $\mathrm{v}$ teórii dokazovania trestného práva nové vedecké poznatky, pretože táto téma nie je v našich podmienkach zásadnejšie rozpracovaná, pričom dôsledné uplatňovanie dokazovania skutočností, ktoré treba dokázat' a ktoré sa len dokazujú v rozhodovacej praxi má potenciál zásadne zvýšit' kvalitu dokazovania všeobecne. Zvlášt však $\mathrm{v}$ rámci insolvenčných trestných veciach, $\mathrm{v}$ ktorých máme na Slovensku pomerne málo úspešne ukončených trestných konaní a to napriek vysokej latencii týchto trestných činov.
\end{abstract}

\section{Kl’účové slová:}

trestné konanie, dokazovanie v trestnom konaní, trestný čin, insolvenčný trestný čin, insolvencia

\section{Subject and Scope of Proving Insolvency Crimes}

\begin{abstract}
:
BURDA, Eduard: Subject and scope of proving insolvency crimes. This scientific article analyzes the legal definition of evidence in criminal proceedings, including the determination of facts that have to be proving and facts that have to be proved and addresses the specifics of the subject and scope of evidence in criminal proceeding concerning insolvency offenses. From this point of view, the scientific article brings new scientific knowledge in the theory of the taking of evidence in criminal law, as this topic has not been more fundamentally elaborated in our conditions, whereas the consistent application of the evidence to be proved and which is only proved in decision-making practice has the potential to substantially increase the quality of the taking of evidence in general. However, this is especially true in the context of insolvency criminal cases, related to which we have relatively few successfully completed criminal proceedings in Slovakia, despite the high latency of these offenses.
\end{abstract}

1 Tento vedecký článok je podporený Agentúrou na podporu výskumu a vývoja na základe Zmluvy č. APVV-15-0740 Návody a nástroje na efektívnu elimináciu protiprávnych konaní v spojení s možnou insolvenciou /Guidelines and tools for effective elimination of unlawful acts in relation with potential insolvency

* Doc. JUDr. Eduard Burda, PhD., Univerzita Komenského v Bratislave, Právnická fakulta, Katedra trestného práva, kriminológie a kriminalistiky. 


\section{Keywords:}

criminal proceedings, taking evidence in criminal proceedings, crime, insolvency crime, insolvency

\section{I. Úvod}

$\mathrm{Na}$ veritel'sko-dlžníckych vzt’ahoch je postavené celé fungovanie trhovej ekonomiky. Vyskytujú sa takmer v každom podnikatel'skom vzt'ahu, sú však prítomné aj v tých najbežnejších ekonomicko-právnych vzt’ahoch každej fyzickej alebo právnickej osoby. Vel'mi častým problémom destabilizujúcim prostredie trhovej ekonomiky je insolvencia subjektov ekonomicko-právnych vzt'ahov, ktorej sa nedá úplne zabránit', niekedy však býva jej dôvodom podvodná činnost' subjektov ekonomicko-právnych vzt'ahov a v takomto prípade prichádza na rad úloha trestného práva, ktoré by sa malo snažit takéto prípady efektívne postihovat', a tým pádom prispievat' ku generálnej prevencii a teda ku stabilite celého systému. Slovenská republika, ako ešte stále postkomunistický štát s rozvíjajúcimi sa ekonomickými vzt’ahmi i právnym prostredím do podoby vyspelého kapitalistického štátu, bola najmä v prvých rokoch svojej existencie charakteristická divokými ekonomickými vztahmi, ktoré si častokrát zamieňali slobodu so svojvôlou. Vymožitel'nost' práva bola práve na začiatku nástupu k trhovej ekonomike nízka a aj ked’ sa v posledných rokoch zlepšuje, ešte stále je v tejto oblasti čo doháňat'.

Insolvenčné trestné činy sú takými trestnými činmi, ktoré postihujú podvodné praktiky páchatel'ov spojené s ich neschopnost'ou alebo zdanlivou neschopnost'ou splácat' splatné záväzky. V zákone č. 300/2005 Z.z. Trestný zákon v znení neskorších predpisov (d’alej len „Trestný zákon“ alebo „TZ“) sú formulované najmä tieto insolvenčné trestné činy: trestný čin poškodzovania veritel’a podl’a $\$ 239 \mathrm{TZ}$, trestný čin zvýhodňovania veritel'a podl'a $\S 240 \mathrm{TZ}$, trestný čin marenia exekučného konania podl'a $§ 243$ a TZ, trestný čin marenia konkurzného konania podl’a $\$ 242 \mathrm{TZ}$, trestný čin nekalej likvidácie podl’a $\S 251 \mathrm{~b}$ TZ, trestný čin podvodného úpadku podl’a $\S 227$ TZ a zavineného úpadku podl'a $\S 228 \mathrm{TZ}$. $^{2}$

Z praktického hl'adiska je nutné venovat' zvýšenú pozornost' procesu dokazovania insolvenčných trestných činov, pretože tieto trestné činy sú častokrát značne latentné a orgány činné v trestnom konaní práve kvôli zložitosti dokazovania často odmietajú trestné oznámenia na insolvenčné trestné činy s poukazom na uplatňovanie princípu ultima ratio trestného práva a na to, že ide o vzt’ahy súkromnoprávnej povahy. Takýto prístup orgánov činných $\mathrm{v}$ trestnom konaní však vedie k prehlbovaniu destabilizácie ekonomického prostredia a rozhodne sa s ním nemožno stotožnit'. Práve preto sa tento vedecký článok zameriava na problematiku predmetu a rozsahu dokazovania insolvenčných trestných činov.

Dokazovanie $\mathbf{v}$ trestnom konaní je zákonom upravený postup subjektov trestného konania (orgánov činných v trestnom konaní, súdu, obvineného, poškodeného,

2 K tomu bližšie pozri napr. ŠAMKO, P. Trestné činy poškodzujúce veritel'ov. Bratislava : Wolters Kluwer, 2019. 
zúčastnenej osoby, oznamovatel’a trestného činu, ktorý nie je poškodeným, atd'.), ${ }^{3}$ ktorého účelom je vyhl'adat', zabezpečit', vykonat' a zhodnotit' informácie dôležité pre poznanie skutkových okolností, na základe ktorých sa v trestnom konaní rozhoduje predovšetkým o vine a treste obvineného, ale aj o d’alších právne relevantných skutočnostiach (napr. o nároku poškodeného na náhradu škody) vrátane rozhodnutí o procesnom postupe $\mathrm{v}$ trestnom konaní (napr. rozhodnutie o väzbe, rozhodnutie o vykonaní d’alšieho výsluchu a pod.).

Predmet dokazovania v trestnom konaní, s ktorým úzko súvisí aj rozsah dokazovania ustanovuje $\S 119$ ods. 1 zákona č. 301/2005 Z.z. Trestný poriadok v znení neskorších predpisov (d’alej len „Trestný poriadok“ alebo „TP“) a to demonštratívnym výpočtom skutočností, ktoré sa $\mathrm{v}$ trestnom konaní dokazujú. $\mathrm{V}$ prípade tohto ustanovenia ide o skutočnosti dôležité pre rozhodnutie vo veci samej (o vine a treste).

Ustanovenie $\S 119$ ods. 1 TP: ,,V trestnom konani treba dokazovat' najmä

a) či sa stal skutok a či má znaky trestného činu,

b) kto tento skutok spáchal a $z$ akých pohnútok,

c) závažnost' činu vrátane príčin a podmienok jeho spáchania,

d) osobné pomery páchatel'a $v$ rozsahu potrebnom na určenie druhu a výmery trestu a uloženie ochranného opatrenia a iné rozhodnutia,

e) následok a výšku škody spôsobenú trestným činom,

f) výnosy z trestnej činnosti a prostriedky na jej spáchanie, ich umiestnenie, povahu, stav a cenu,

g) majetkové pomery na účely odňatia výnosov z trestnej činnosti. “

Rozsahom dokazovania definujeme hranice dokazovania, množstvo a kvalitu dôkazov, ktorými má byt' preukázaný predmet dokazovania. Rozsah dokazovania sa odlišuje vzhl'adom na štádium trestného konania, v ktorom je realizovaný (iný rozsah dôkazov je potrebný na podanie obžaloby, iný na vynesenie odsudzujúceho rozsudku, kde je rozsah dokazovania širší) aj vzhl'adom na konkrétnu vec. Rozsah dokazovania je pritom rámcovo určený zásadou zistenia skutkového stavu bez dôvodných pochybností. ${ }^{4}$

\section{Skutočnosti, ktoré sa musia dokázat' a ktoré stačí dokazovat'}

Predmetné ustanovenie $\S 119$ ods. 1 TP konštatuje, čo treba v trestnom konaní dokazovat', z ustanovenia však nie je prvoplánovo jasné, čo z daných skutočností je nevyhnutné dokázat' a čo sa prípadne síce v konkrétnom prípade tiež dokazovat' musí, ale pre rozhodnutie to nie je nevyhnutné. Toto je otázka, ktorú je potrebné vyriešit', pretože dokazovat' sa podl'a $\S 119$ ods. 1 TP majú aj skutočnosti, ktoré v konkrétnom prípade nebudú môct' byt' dokázané, avšak z hl'adiska objasnenia skutku a jeho páchatel'a a spravodlivého potrestania páchatel’a máme dostatok dôkazov na spravodlivý odsudzujúci rozsudok

3 Vnímanie dokazovania ako postupu orgánov činných v trestnom konaní a súdu a až následne aj ako postupu d’alších osôb s procesnými právami, ktoré prakticky len reagujú na postup orgánov činných v trestnom konaní a súdu, nie je správne, pretože posilnenie prvkov kontradiktórnosti súdneho konania s významným vplyvom aj na prípravné konanie, evidentne posilnilo vplyv všetkých subjektov trestného konania na dokazovanie. K definícii dokazovania pozri bližšie napríklad: ŠÁMAL, P. a kol. Trestní rád. Komentár̆ - díl I. 6. vydání. Praha : C. H. Beck, 2008, s. 754.

4 VIKTORYOVÁ, J. Dokazovanie. In Ivor, J. a kol. Trestné právo procesné. Bratislava : IURA EDITION, 2006, s. 427. 
(napr. pri politickom atentáte neznámeho atentátnika zo zahraničia zadržia v momente, ked' sa chystal vystrelit', avšak atentátnik odmieta čokol'vek prezradit' a jeho skutočná totožnost' ako aj d’alšie skutočnosti typu motivácie či osobných pomerov zostávajú skryté). Aj ked' sa na prvý pohl'ad zdá, že takéto prípady nehrozia pri insolvenčných trestných činoch, pretože pre ich dokázanie je zväčša potrebné dokázat' neschopnost' plnit' splatné záväzky, čo predpokladá znalost' identity páchatel'a a tiež preto, že sa predpokladá, že sa páchatel' a poškodený poznajú, nemusí tomu tak byt' vždy. V prvom rade, vel'a obdobných trestných činov sa pácha prostredníctvom internetu, kedy skutočná identita páchatel’a býva často problematicky zistitelná (v takomto prípade sa však trestný čin bud' nepodarí objasnit', alebo sa k mnohých dôležitým údajom napokon OČTK dostane a teda nemusí byt' prítomný problém s identifikáciou páchatel’a), v druhom rade sa môžu vyskytnút', aj ked' raritne, prípady, kedy páchatel' vystupuje, prípadne aj podniká, pod falošnou identitou a pravú sa napokon zistit' nepodarí (za súčasného objasnenia takéhoto činu však nepoznám v slovenskej trestnoprávnej praxi jediný prípad).

Pre rozhodnutie vo veci samej je vždy potrebné obligatórne dokázat' zo skutočností uvedených v § 119 ods. 1 pod písmenom a) až g) TP (inak napríklad nie je možné vydat' odsudzujúci rozsudok) tieto skutočnosti:

a) či sa stal skutok a či má znaky trestného činu (§ 119 ods. 1 písm. a) TP),

b) kto tento skutok spáchal (§ 119 ods. 1 písm. b) TP),

c) závažnost' činu ( $\$ 119$ ods. 1 písm. c) TP),

d) následok trestného činu (výšku škody spôsobenú trestným činom - dokázat' ju je nevyhnutné, len ak je trestným činom spôsobená škoda ako obligatórny znak trestného činu, v prípade insolvenčných trestných činov však zväčša ide o obligatórny znak a v zásade ani nie je v praxi problém výšku tejto škody dokázat'), (§ 119 ods. 1 písm. e) TP),

Predmetné skutočnosti sú všetko obligatórne znaky trestného činu okrem závažnosti trestného činu, ktorý je obligatórnym znakom len $\mathrm{v}$ prípade prečinu (pokial' striktne netrváme na tom, že ustanovenie $\S 10$ ods. $2 \mathrm{TZ}$ je len materiálnym korektívom prečinu a nie materiálnym znakom prečinu). Zároveň však treba povedat', že závažnost' trestného činu sa na elementárnej úrovni dá vždy dokázat', ak sa zároveň dajú dokázat' aj d’alšie skutočnosti, ktoré je potrebné obligatórne dokázat'. Preto súhrn týchto skutočností musí byt' nielen dokazovaný, ale aj dokázaný, ak sa má rozhodnút' odsudzujúcim rozsudkom o vine obvineného a sankcii pre obvineného.

Na druhej strane v ustanovení § 119 ods. 1 TP sú pod písmenami a) až g) uvedené aj okolnosti, ktoré sa síce vždy musia obligatórne dokazovat', ak sa ich ale v konkrétnom prípade nepodarí preukázat', nie je to na prekážku rozhodnutia vo veci samej (o vine a sankcii, ani na prekážku odsudzujúcemu rozsudku s výrokom o treste, resp. o uložení ochranného opatrenia). Ide o tieto skutočnosti:

a) z akých pohnútok spáchal páchatel' trestný čin (§ 119 ods. 1 písm. b) TP),

b) príčiny a podmienky spáchania trestného činu (§119 ods. 1 písm. c) TP) - aj ked' nejaké podmienky spáchania trestného činu ako skutočnosti existujúce v objektívnej realite sa vždy podarí preukázat' (napr. vznik záväzkovo-právneho vzt’ahu), príčiny trestného činu, pokial' ich vnímame ako subjektívne skutočnosti závislé od osoby či od osobnosti páchatel'a ${ }^{5}$, sa nám v konkrétnom prípade nemusí podarit' preukázat'

5 K tomu bližšie pozri napr. TURAYOVÁ, Y. Kriminologické aspekty zločinu. Bratislava : IURA 
(napr. obvinený vôbec nevypovedá a nepoznáme konkrétne problémy, prečo sa dostal do insolvencie, pretože čast' jeho majetku jednoducho zmizla),

c) osobné pomery páchatel'a $\mathrm{v}$ rozsahu potrebnom na určenie druhu a výmery trestu a uloženie ochranného opatrenia a iné rozhodnutia (\$119 ods. 1 písm. d) TP),

d) výšku škody spôsobenú trestným činom (§ 119 ods. 1 písm. e) TP) - za predpokladu, že v danej skutkovej podstate trestného činu nejde o obligatórny znak, čo je v prípade insolvenčných trestných činov väčšinou irelevantné),

e) výnosy z trestnej činnosti a prostriedky na jej spáchanie, ich umiestnenie, povahu, stav a cenu (§ 119 ods. 1 písm. f) TP) - pri insolvenčných trestných činoch sa výnosy z trestnej činnosti dokazujú pomerne l'ahko, horšie je to v prípade ich umiestnenia, ich povahy a stavu, zvlášt' ked' ide o insolvenciu, teda ked' je čast' týchto prostriedkov bud' už mimo dispozičnej sféry obvineného alebo ich obvinený dobre ukryl,

f) majetkové pomery na účely odňatia výnosov z trestnej činnosti (§ 119 ods. 1 písm. g TP).

Ako sme už uviedli vyššie, musíme si uvedomit', že aj ked' výnimočne, môžu sa vyskytnút' prípady, v ktorých o obvinenom nevieme prakticky vôbec nič, akurát mu vieme dokázat' spáchanie trestného činu. Nedokázanie týchto d'alších skutočností uvedených v $\S 119$ ods. 1 TP však nesmie byt' prekážkou pre rozhodnutie vo veci samej vrátane odsudzujúceho rozsudku, pretože opačný prípad by bol nielen nespravodlivý, ale aj neodôvodnený (nemôžeme predsa pustit' zjavného páchatel'a len preto, že o ňom nevieme nič d'alšieho zistit').

\section{Dokazovanie, či sa skutok stal a či má znaky trestného činu}

Podl'a ustanovenia $§ 119$ ods. 1 písm. a) TP sa v trestnom konaní dokazuje, či sa stal skutok a či má znaky trestného činu. V každom právnom štáte sa aplikuje zásada ,žiadny trestný čin bez zákona,“ preto je v trestnom konaní nevyhnutné zistit', či sa skutok po vecnej stránke naozaj stal a ak áno, treba následne aj dokázat', že sa naozaj stal vrátane detailov jeho spáchania (napr. čas, miesto spáchania, spôsob spáchania a pod.). Výrok o vine môže byt' založený len na takých dôkazoch, ktoré celkom vylučujú pochybnost', že sa stal skutok, ktorý je predmetom trestného stíhania. ${ }^{6}$

Predmetom trestného stíhania je vždy skutok, v ktorom je badaný trestný čin, pričom podstatou skutku je trestnoprávne relevantné konanie páchatel'a a ním zapríčinený trestnoprávne významný následok. Od skutku je nutné odlišovat jeho opis, ktorý musí obsahovat' tie skutkové okolnosti, ktoré sú právne významné z hl'adiska naplnenia jednotlivých znakov skutkovej podstaty trestného činu. ${ }^{7}$ Momentom, ktorý delí páchatel’ovo konanie na rôzne skutky, je následok závažný z hl'adiska trestného práva, ktorý páchatel' spôsobil alebo chcel spôsobit'. Za jeden skutok možno považovat' len tie prejavy vôle páchatel'a navonok, ktoré sú pre tento následok kauzálne, pokial' sú zahrnuté jeho zavinením. ${ }^{8}$ Ak ide o viac spôsobených následkov významných

EDITION, 2001, s. 133.

6 K tomu porovnaj R 14/1964.

7 K tomu porovnaj judikát Najvyššieho súdu ČR R 41/2002.

$8 \mathrm{~K}$ tomu porovnaj R 8/1985. 
z hl'adiska trestného práva hmotného, ide o jeden skutok vtedy, ak všetky následky boli spôsobené aspoň sčasti jedným konaním, rovnako významným z hladiska trestného práva hmotného. ${ }^{9} \mathbf{V}$ prípade insolvenčných trestných činov ide častokrát o pomerne zložité skutky zložené $z$ viacerých čiastkových útokov (napr. právne a faktické kroky zbavenia sa alebo ukrytia majetku) ako aj prípravných fáz týchto čiastkových útokov (napr. príprava zmluvy o prevode nehnutel'nosti, predtým jej dohodnutie), ktoré tvoria trestný čin častokrát až $v$ ich súhrne (hromadný trestný čin), (napr. až zbavenie sa domu a dvoch áut predstavuje zmarenie uspokojenia veritel'a).

Ak sa aj preukáže vykonanie konkrétneho skutku, tento zároveň musí napíñat' všetky znaky trestného činu, teda musí byt' protiprávny vychádzajúc z protiprávnosti stanovenej Trestným zákonom (nestačí všeobecná konštatácia o akejkol’vek protiprávnosti), musí naplńat' obligatórne znaky konkrétnej skutkovej podstaty daného trestného činu. Insolvenčné trestné činy sú úmyselné trestné činy a preto je klúǔcové v rámci ich dokazovania preukázat' úmyselné zavinenie (aspoň nepriamy úmysel) a to vo vzt'ahu ku všetkým vonkajším znakom trestného činu, čo je pri väčšine insolvenčných trestných činov fakt, že páchatel' je aspoň uzrozumený s tým, že uspokojenie jeho veritel'a bude aspoň čiastočne zmarené. Preukazovanie zavinenia (vnútorného vzt'ahu páchatel'a $\mathrm{k}$ následku svojho konania) je možné aj na základe objektívnych skutočností). ${ }^{10} \mathrm{~V}$ prípade insolvenčných trestných činov ak ide o priemerne uvažujúceho páchatel'a postačí na dokázanie úmyselnej formy zavinenia to, že páchatel' sa zbavil majetku (bez náležitej protihodnoty) alebo znížil jeho hodnotu pod hranicu hodnoty (napr. predal svoj byt kamarátovi za polovičnú sumu trhovej hodnoty), z ktorej nie je možné uspokojit' veritel'a.

$\mathrm{V}$ prípade prečinu musí byt' preukázaná dostatočná závažnost' prečinu, respektíve že závažnost' prečinu nie je nepatrná v zmysle $\S 10$ ods. $2 \mathrm{TZ}$, v prípade mladistvých nie je malá v zmysle $\S 95$ ods. 2 TZ a to obligatórne v pri každom prečine. Pri nedostatočnom preukázaní okolností, a prípadne i pri ich nedostatočnom vyhodnotení, že prečin má vyššiu závažnost' ako je nepatrná závažnost' (v prípade mladistvých osôb malá závažnost'), nemôže príst' $k$ rozhodnutiu vo veci samej v neprospech obvineného, pretože je nevyhnutné aplikovat' zásadu $\mathrm{v}$ pochybnostiach $\mathrm{v}$ prospech obvineného.

\section{Dokazovanie, kto skutok, ktorý je trestným činom, spáchal a z akých pohnútok}

Podl'a ustanovenia $§ 119$ ods. 1 písm. b) TP sa v trestnom konaní dokazuje, kto skutok, ktorý je trestným činom spáchal a z akých pohnútok.

Pre vznesenie obvinenia je nevyhnutné, aby orgány činné v trestnom konaní najskôr určili (predtým prípadne vypátrali) podozrivú osobu. Ak je odôvodnený predpoklad podporený dôkazmi, že táto osoba spáchala daný skutok, je proti nej vznesené obvinenie a stane sa obvineným. O čo neskoršie štádium trestného konania od vznesenia obvinenia až po rozhodnutie vo veci ide, musí pravdepodobnost', že obvinený naozaj spáchal daný trestný čin narastat', až po istotu, že bol pritom zistený skutkový stav veci, o ktorom nie sú dôvodné pochybnosti, a to v rozsahu nevyhnutnom na ich

$9 \mathrm{~K}$ tomu porovnaj R 5/1988.

10 K tomu porovnaj rozsudok Najvyššieho súdu SR; sp. zn. 1 Tzo V/2005. 
rozhodnutie.

V prípade, že sú $\mathrm{v}$ danom štádiu trestného konania závažné dôvodné pochybnosti, že trestný čin nespáchal daný obvinený, je nevyhnutné ho obvinenia zbavit', pričom o čo neskoršie štádium trestného konania ide, o to menej dôvodných pochybností stačí na zbavenie obvinenia, pretože v úvodných štádiách trestného konania sa skutkový stav iba zist'uje, informácie sa intenzívne preverujú.

Pokial' ide o pohnútky spáchania trestného činu, tie súvisia s príčinami trestného činu ( $\mathrm{k}$ tomu bližšie výklad $\mathrm{k}$ bodu $\mathrm{V}$ ).

V prípade insolvenčných trestných činov je zväčša nepochybné, kto spáchal trestný čin, pretože konkrétna osoba dlhuje určité plnenie inej osobe a zároveň sa skúma nemožnost' plnenia vo vzt'ahu k poškodenému. Prípady súvisiace so zámenou identity sú skôr raritné. Väčší problém nastáva $\mathrm{v}$ prípadoch trestných činov spáchaných vo virtuálnom priestore, ktoré sú pomerne časté. Tu však treba povedat', že aby sa mohli dokázat' znaky skutkovej podstaty niektorého z insolvenčných trestných činov, zároveň je potrebné preukázat' aj konkrétnu osobu, ktorá sa tohto trestného činu dopustila (ak ju nepreukážeme, potom nepoznáme ani jej majetkové pomery a fakt, či majetok klesol pod hodnotu, pri ktorej hrozí, že veritel' aspoň čiastočne nebude uspokojený).

\section{Dokazovanie závažnosti činu vrátane príčin a podmienok jeho spáchania}

Podl'a ustanovenia § 119 ods. 1 písm. c) TP sa v trestnom konaní dokazuje závažnost’ činu vrátane príčin a podmienok jeho spáchania.

Závažnost' činu sa v prípade prečinov dokazuje aj z dôvodu, aby sa určilo, či bol naplnený materiálny znak, materiálny korektív prečinu (§ 10 ods. 2 TZ, pri mladistvých osobách $\S 95$ ods. $2 \mathrm{TZ}$ ), zároveň je tento znak súčastou protiprávnosti prečinu.

Závažnost' prečinu je podl'a $\S 10$ ods. $2 \mathrm{TZ}$ formovaná nasledujúcimi faktormi (taxatívny výpočet):

a) spôsob vykonania činu,

b) následky činu,

c) okolnosti, za ktorých bol čin spáchaný,

d) miera zavinenia

e) pohnútka páchatel'a.

Pri všetkých trestných činoch je závažnost' trestného činu zásadná pri určovaní druhu a výmery trestu. V zmysle $\S 34 \mathrm{TZ}$ pri určovaní druhu trestu a jeho výmery súd prihliadne najmä (demonštratívny výpočet):

a) na spôsob spáchania činu

b) na následok činu,

c) na zavinenie,

d) na pohnútku páchatel'a,

e) na prit’azujúce okolnosti a pol’ahčujúce okolnosti,

f) na osobu páchatel'a, na jeho pomery a možnost' jeho nápravy.

$\mathrm{V}$ prípade insolvenčných trestných činov je závažnost' činu značne determinovaná výškou škody, ako aj tým, ako sa nesplatenie záväzku prejaví na poškodenom. Závažnost' činu je vel'mi vysoká najmä v prípadoch, ktoré vedú $\mathrm{k}$ tzv. druhotnej platobnej neschopnosti či ku krachu veritel'a alebo v prípade fyzických osôb k tomu, že 
veritel' príde o byt alebo dom, v ktorom reálne žije.

,Skúmanie príčin a podmienok činu vrátane jeho pohnútok má vel'ký význam pri individualizácii trestu (sankcie), aby bol trest primeraný, ale aj aby mohol byt' voči páchatel’ovi trestného činu zvolený taký postup, ktorý by zaručoval čo najväčšiu pravdepodobnost nápravy. Skúmanie príčin a podmienok trestnej činnosti prostredníctvom súhrnu viacerých trestných činov rovnakého druhu a podobnej závažnosti má význam na nastavenie generálnej prevencie. Túto svoju povinnost' však orgány činné v trestnom konani a súdy, ako vyplýva z výskumov, ${ }^{11}$ opominajú, č je škoda, pretože trestná politika štátu sa potom zameriava viac na sankcionovanie páchatel'ov trestnej činnosti, než na aktivnu prevenciu. Takýmto prístupom nemáme šancu znižovat' kriminalitu.“"12

Príčinná súvislost', príčinný vzt’ah, tvorí bazálny predpoklad fungovania javov v prírode i spoločnosti, právo a kriminológiu nevynímajúc. Príčinná súvislost' je „... objektívne reálne existujúcu súvislost' javov, ktorá nie je závislá na človeku, ktorý túto súvislost'v konkrétnom prípade zistuje. Každý jav je následkom celého radu prićin a sám je opät príčinou d'alšich javov...." ${ }^{\prime 3}$ „... nie je javu bez prićiny, ani príčiny bez účinku; nie je žiadna prvá prícina, lebo jav - prvá prícina by bol potom bez príčiny." ${ }^{14}$ Pre podrobné vedecké skúmanie príčinnosti trestných činov je dôležité d'alšie delenie príčin v širšom zmysle slova, ako súčastí príčinnej súvislosti, a to na príčiny v užšom zmysle slova, ktoré ako najpodstatnejšie prvky pri svojom súhrne vyvolávajú účinok (tento súhrn nazývame špecifickou príčinou), a na podmienky pôsobenia príčin, čo sú javy, ktoré sú síce dôležité (a niekedy aj nevyhnutné) pre to, aby vznikla určitá udalost' a aby prebehla určitým spôsobom, ale samy osebe túto udalost' nevyvolávajú. Spolu tvoria tzv. úplnú príčinu. „Prićinný vzt'ah v širšom zmysle zahrína ako pričiny, tak aj podmienky." "15 Skúmanie a dokazovanie pričcin a podmienok trestného činu v zmysle ustanovenia $§ 119$ ods. 1 písm. c) TP má význam primárne z hl'adiska podrobného objasnenia trestného činu, čo je dôležité jednak pri verifikácií jednotlivých skutočností a jednak pri samotnom ustálení závažnosti trestného činu a následného rozhodovania o sankcií. Sekundárne má aj význam z hl'adiska d'alšieho nastavenia prevencie, pri insolvenčných trestných činoch ide najmä o nastavenie súkromnoprávnej legislatívy ako aj osvetu medzi potenciálnymi poškodenými najmä z pohl'adu tzv. finančnej gramotnosti. Preto za príčiny podla $\S$ 119 ods. 1 písm. c) TP považujeme príčiny v užšom zmysle. Vzhl'adom na účel skúmania a dokazovania príčin a podmienok $\mathrm{v}$ trestnom konaní je najvhodnejšie definovanie príčin (v užšom zmysle) a podmienok konkrétneho trestného činu nasledovne: ,... príčina konkrétneho trestného činu má subjektivny charakter, súvisí s motívom, so zavinením, teda predovšetkým s osobnost'ou páchatel'a. Naopak, podmienka spáchania trestného činu má charakter objektívnej skutočnosti. Zväčša existuje bez pričinenia páchatel'a, ktorý ju len využiva, alebo ho provokuje, aby realizoval príčinu a uskutočnil svoj zámer. Exis-

11 K tomu bližšie pozri: TURAYOVÁ, Y. Kriminologické aspekty zločinu. Bratislava : IURA EDITION, 2001, s. 73 - 76 a 132.

12 KOLESÁR, J. Perspektivy dokazovania v trestnom konani s dôrazom na znalecké dokazovanie. Prievidza : Citicom, 2010, s. 14.

13 MADAR, Z. a kol. Právnický slovnik. II. díl. P-Ž. Praha : Orbis, 1978, s. 182.

14 NEZKUSIL, J. a kol. Československá kriminologie. Praha : Panorama, 1978, s. 107.

15 MADAR, Z. a kol. Právnický slovník. II. díl. P-Ž. Praha : Orbis, 1978, s. 182. 
tuje v čase páchania trestného činu mimo osoby páchatel'a."16

Príčiny trestného činu teda majú na rozdiel od podmienok subjektívny charakter, filtrovaný a prispôsobovaný osobnost’ou páchatel’a. Konkrétny trestný čin je spáchaný súborom viacerých spolupôsobiacich príčin, ktoré musia mat' z hl'adiska trestnoprávneho zavinenia bezprostrednú súvislost' $\mathrm{s}$ trestnoprávnym následkom. Kriminologické hl'adisko, ktoré sa však uplatňuje aj v prípade procesného ustanovenia podl'a $§ 119$ ods. 1 písm. c) TP však ide za hranice týchto bezprostredných príčin a skúma okrem nich samotných i príčiny, ktoré im predchádzali a vyvolali ich, a d’alej príčiny podmieňujúce príčiny bezprostredných príčin atd'. (jednoducho vzdialenejšie príčiny, pretože tie majú priamy vplyv na závažnost' trestného činu). Tento jav nazývame ret’azenie prićcin a umožňuje nám hlbšie pochopit' osobnost' páchatel'a, jeho motívy, „osud“ i prostredie, ktoré ho formovalo (napr. páchatel' vylákal od svojho brata peniaze, ktoré premrhal $\mathrm{v}$ rulete a následne previedol svoj byt na druhého brata, bezprostredná príčina bola nezodpovedné nakladanie s finančnými prostriedkami a obavy $\mathrm{z}$ toho, že mu to brat od ktorého si požičal peniaze neodpustí, vzdialenejšia príčina je celkovo nezodpovedný prístup páchatel’a $\mathrm{k}$ finančným otázkam, ten je spôsobený kombináciou faktorov nedostatočnej výchovy v tejto oblasti a vznikom závislosti na hazardných hrách).

Podmienkou spáchania konkrétneho trestného činu je každý jav iný ako príčina trestného činu, ak aspoň čiastočne ovplyvní priebeh alebo následok tohto trestného činu, (alebo je na to aspoň potenciálne spôsobilý a pri páchaní trestného činu sa objektívne vyskytuje), bez ohl'adu na to, či by bez tohoto javu bol trestný čin spáchaný alebo nie (napr. podmienkou insolvenčného trestného činu môže byt' prílišná dôverčivost' poškodeného, jeho nedostatočné orientovanie sa pri zodpovednom investovaní, zároveň môže byt' podmienkou nedostatočná legislatíva).

\section{Dokazovanie osobných pomerov páchatel’a}

Podl'a ustanovenia $§ 119$ ods. 1 písm. d) TP sa v trestnom konaní dokazujú osobné pomery páchatel'a $v$ rozsahu potrebnom na určenie druhu a výmery trestu a uloženie ochranného opatrenia a na iné rozhodnutia. Predmetné ustanovenie akcentuje požiadavku na dokázanie skutočností potrebných pre individualizácia sankcie, pričom tá má v prvom rade plnit’ resocializačnú funkciu a pokial' možno má zabezpečit čo najhladšie následné začlenenie páchatel’a do spoločnosti.

Pojem osobné pomery páchatel'a zahŕňa celé spektrum skutočností charakterizujúcich prevažne:

a) fyzické a mentálne vlastnosti a schopnosti (zvlášt' znížené mentálne schopnosti sú v prospech obvineného; lepšie fyzické a duševné schopnosti pre páchanie určitého druhu trestnej činnosti svedčia skôr v neprospech obvineného),

b) vzdelanie (jeho význam pre trestné konanie závisí vždy od charakteru trestného činu, kvalitné ekonomické vzdelanie napríklad zvyšuje nebezpečnost’ páchatel'a pri páchaní ekonomických trestných činov vrátane insolvenčných trestných činov.)

c) zručnosti (napr., ovláda hackering alebo právny poriadok daňových rajov, v ktorom sa dajú dobre zašantročit' financie - ak pri páchaní trestných činov obvinený využíva tieto zručnosti, sú mu skôr na prítaž),

16 TURAYOVÁ, Y. Kriminologické aspekty zločinu. Bratislava : Iura Edition, 2001, s. 133. 
d) záujmy (mierumilovné záujmy a najmä spoločensky prospešné záujmy sú skôr v prospech obvineného - napr. dobrovol'nícka činnost'v domove sociálnych služieb alebo pestovanie ruží; záujmy, ktoré podnecujú alebo ul'ahčujú danú trestnú činnost' sú skôr na prítaž obvinenému, napr. sledovanie búrz činností pri ekonomickej trestnej činnosti),

e) sociálne a ekonomické postavenie (horšie ekonomické postavenie svedčí skôr $\mathrm{v}$ prospech obvineného, ak si ho nespôsobil sám svojím lajdáckym prístupom k životu, pri sociálnom postavení vel'mi záleží práve od toho, či si jeho zhoršenie zapríčinil obvinený sám),

f) citové väzby v rodine a k priatel'om a pod.,

g) prognózu resocializácie páchatel’a,

h) konkrétne skutky páchatel'a z minulosti či už pozitívne alebo negatívne, či už v súlade s právom alebo protiprávne, ktoré poukazujú na spôsob jeho myslenia a správania sa.

Predmetné skutočnosti charakterizujúce páchatel'a, jeho osobnost' a resocializačné prognózy treba vždy hodnotit' $v$ ich súhrne a netreba absolutizovat' len jednu z nich (pokial' nie je rozhodujúca pre danú trestnú činnost' - napr. pri insolvenčných trestných činoch ledabolý prístup $\mathrm{k}$ financiám a následné zatajovanie majetku), v konečnom dôsledku ak niekto pácha sofistikovanejšiu trestnú činnost', je pochopitel'né, že má zároveň aj vzdelanie či záujmy, ktoré mu ju pomôžu realizovat' (napr. pri páchaní ekonomickej trestnej činnosti alebo počítačovej trestnej činnosti).

Osobné pomery páchatel'a netreba, a vlastne to ani nie je fyzicky možné, dokazovat' $v$ celom rozsahu, ale len $\mathbf{v}$ rozsahu potrebnom na určenie druhu a výmery trestu a uloženie ochranného opatrenia a na iné rozhodnutia, najmä procesného charakteru, či už ide o zaist'ovacieho opatrenia (napr. rozhodnutie o väzbe alebo o zaistení majetku) alebo o výkone sankcií.

\section{Dokazovanie následku trestného činu a výšky škody spôsobenej trestným činom}

Podl’a ustanovenia $§ 119$ ods. 1 písm. e) TP sa v trestnom konaní dokazuje následok trestného činu a výška škody spôsobenej trestným činom.

Následok trestného činu je obligatórny znak skutkovej podstaty trestného činu, ktorý sa ako súčast' objektívnej stránky trestného činu prejavuje na objekte trestného činu. Ustanovenie $\S 119$ ods. 1 písm. e) TP aj vzhl’adom k tomu, že celý tento odsek je formulovaný ako demonštratívny výpočet dokazovaných skutočností, treba však chápat' širšie ako len dokazovanie následku ako obligatórneho znaku trestného činu. Treba ho chápat' ako dokazovanie komplexnejších, v príčinnej súvislosti vzdialenejších, aj ked' spoločensky významných následkov trestného činu, ktoré môžu mat' tiež vel'ký význam pre individualizáciu trestu (napr. zvýhodnenie veritel'a bolo spáchané voči živitel'ovi siedmich detí, ktorý patrí do nízkopríjmovej skupiny obyvatel'stva). Pojmy škoda spôsobená trestným činom a výška škody (ktoré sú tiež následkom trestného činu) sú bližšie definované v $\S 124$ až $126 \mathrm{TZ}$.

Pri insolvenčných trestných činoch je vždy mimoriadne podstatným následkom relevantným väčšinou aj z hl’adiska obligatórnosti znakov trestného činu výška škody vyjadritel'ná v peniazoch. Ani pri insolvenčných trestných činoch však netreba opo- 
mínat' následok trestného činu v širšom zmysle slova, pretože ten býva často významný, pretože následkom insolvenčných trestných činov často dochádza $\mathrm{k}$ druhotnej platobnej neschopnosti, ku krachom živnostníkov i firiem, k zvyšovaniu nezamestnanosti a k celkovému hospodárskemu úpadku krajiny. Preto prípadné podceňovanie týchto trestných činov je vrcholne nenáležité.

\section{Dokazovanie výnosov z trestnej činnosti a prostriedky na jej spáchanie, ich umiestnenie, povahu, stav a cenu}

Podl’a ustanovenia $§ 119$ ods. 1 písm. f) TP sa v trestnom konaní dokazujú aj výnosy $z$ trestnej činnosti a prostriedky na jej spáchanie, ich umiestnenie, povahu, stav a cenu.

Odhalenie výnosov z trestnej činnosti a prostriedkov pripravených na jej spáchanie vrátane ich umiestnenia, povahy, stavu a ceny jednak objasňuje detaily konkrétneho vyšetrovaného trestného činu, čo je zvlášt' dôležité pri ekonomických trestných činoch, insolvenčné trestné činy nevynímajúc, jednak môže prispiet' k odhaleniu d'alších trestných činov či dokonca celých organizovaných, zločineckých, teroristických alebo extrémistických skupín.

Predmetné výnosy a prostriedky pochádzajúce z trestnej činnosti alebo určené na trestnú činnost' je potrebné zákonným spôsobom odňat' z dispozičnej sféry páchatel'ov trestných činov a d'alších osôb s nimi spojených, čo prispieva $\mathrm{k}$ celkovému oslabovaniu organizovaného zločinu. Výnosy z trestnej činnosti a prostriedky na jej spáchanie tiež môžu byt' využité v prospech poškodených na náhradu škody.

Výnosy z trestnej činnosti sú legálne definované v $§ 130$ ods. 9 TP: ,Výnosom z trestnej činnosti sa na účely tohto zákona rozumie

a) vec, ktorá bola získaná trestným činom,

b) vec, ktorá bola získaná ako odmena za trestný čin,

c) vec, ktorá bola nadobudnutá, hoci aj len sčasti za vec, ktorá bola získaná trestným činom alebo ako odmena zan̆,

d) vec, na ktorú bola hoci aj len sčasti premenená vec, ktorá bola získaná trestným činom alebo ako odmena zan̆, alebo

e) plody a úžitky veci uvedenej v písmenách a) až d). “.

Prostriedky určené na spáchanie trestnej činnosti sú všetky veci určené na spáchanie trestnej činnosti.

Povaha výnosov z trestnej činnosti alebo prostriedkov určených na jej spáchanie znamená, že sa má dokazovat', či ide o výnosy alebo prostriedky v podobe peňazí v hotovosti, peňazí na účte v banke, virtuálnych peňazí, cenných papierov, alebo $\mathrm{v}$ podobe hnutel'ných vecí a akých alebo v podobe nehnutel'ných vecí a akých, práv duševného vlastníctva alebo iných práv a akých. V prípade peňazí ide aj o menu a tiež v prípade cenných papierov o menu, ktorej ekvivalent predstavujú (ak má cenný papier takú povahu).

Stav výnosov z trestnej činnosti alebo prostriedkov určených na jej spáchanie znamená v prípade peňazí a práv aj ich dostupnost' pre OČTK a súdy (napr. treba vyhodnotit' ak sú peniaze v hotovosti schované na neznámom mieste alebo sú na účte v banke na Kajmanských ostrovoch a OČTK sa k nim jednoducho nedostanú alebo vymožitel'nost' práv vychádzajúcich z autorského práva v Nigérii), v prípade 
ostatných vecí ide o popis ich fyzickej kvantity a kvality. Spolu so stavom veci je potrebné dokázat' ich umiestnenie, teda kde sa fyzicky alebo vo virtuálnom priestore nachádzajú (napr. peniaze na účte v banke alebo databáza na internete a aký je možný prístup $\mathrm{k}$ nej), v prípade práv ako ich možno uplatnit' (stačí všeobecný popis, nie vyčerpávajúci popis procedúry). S povahou, stavom a umiestnením predmetných výnosov súvisí aj ich cena, teda hodnota vyjadritel'ná v peniazoch.

Cena výnosov $\mathrm{z}$ trestnej činnosti alebo prostriedkov určených na jej spáchanie sa určuje obdobne, ako sa určuje výška škody podl'a ustanovenia $§ 126$ TZ. Teda sa vychádza z ceny, za ktorú sa vec, ktorá bola predmetom útoku, $\mathrm{v}$ čase a $\mathrm{v}$ mieste činu obvykle predáva. Ak cenu nemožno takto zistit', vychádza sa z účelne vynaložených nákladov na obstaranie rovnakej alebo obdobnej veci alebo na uvedenie veci do predošlého stavu. Ak nemožno určit' cenu ani jedným z týchto spôsobov alebo ak sú vážne pochybnosti o správnosti takto určenej ceny, určí sa jej výška na podklade odborného vyjadrenia alebo potvrdenia právnickej osoby, ktorej pôsobnost' alebo predmet činnosti poskytuje záruku objektívnosti určenia ceny; inak sa výška ceny určí na podklade znaleckého posudku. Tento výklad sa opiera o analógiu legis s § $126 \mathrm{TZ}$, ktorá je $\mathrm{v}$ trestnom procese $\mathrm{v}$ mnohých prípadoch, vrátane tohto jediným rozumným postupom, pretože daný procesný postup nie je osobitne riešený a je teda potrebné ho riešit' podl'a povahy najbližšieho zákonom upraveného postupu.

IX. Dokazovanie majetkových pomerov na účely odňatia výnosov z trestnej činnosti.

Podl'a ustanovenia § 119 ods. 1 písm. g) TP sa v trestnom konaní dokazujú aj celkové majetkové pomery obvineného na účely odňatia výnosov $z$ trestnej činnosti.

Súčastou boja proti organizovanému zločinu a proti závažným formám ekonomických trestných činov, kam spadajú aj insolvenčné trestné činy je aj dôsledné odobratie výnosov pochádzajúcich $\mathrm{z}$ trestnej činnosti. A na to, aby sa tieto výnosy mohli spol'ahlivo odobrat', je potrebné určit', čo z majetku obvineného pochádza z týchto výnosov a na to je potrebné nepochybne zistit' celý majetok obvineného.

Podl'a $\S 2$ ods. 1 zákona č. 312/2020 o výkone rozhodnutia o zaistení majetku a správe zaisteného majetku a o zmene a doplnení niektorých zákonov: „,Majetkom sa na účely tohto zákona rozumejú veci podl'a Občianskeho zákonníka, živé zvieratá, práva alebo iné majetkové hodnoty, najmä byty, nebytové priestory, peniaze v hotovosti alebo peniaze vedené na účte v banke alebo pobočke zahraničnej banky a peniazmi ocenitelné hodnoty vrátane virtuálnej meny, okrem jadrového materiálu, rádioaktívneho odpadu, vyhoretého jadrového paliva alebo inštitucionálneho rádioaktivneho odpadu. "

\section{Záver}

Závažnost' insolvenčných trestných činov netreba vôbec podceňovat', pretože, ako už bolo vyššie uvedené, následkom insolvenčných trestných činov často dochádza k druhotnej platobnej neschopnosti, ku krachom živnostníkov i firiem, k zvyšovaniu nezamestnanosti a k celkovému hospodárskemu úpadku krajiny. Som presvedčený, že orgány činné $\mathrm{v}$ trestnom konaní by si v praxi mali dat viac záležat' na prešetrení trestných oznámení, $\mathrm{v}$ ktorých je uvedené podozrenie $\mathrm{z}$ insolvenčných trestných či- 
nov a v prípade, že sa tieto podozrenia potvrdia, venovat' práve procesu dokazovania insolvenčných trestných činov zvýšenú pozornost', aby jednak činy boli spol'ahlivo dokázané a ich páchatel' spravodlivo potrestaný a jednak aby sa zvýšila generálna prevencia tejto trestnej činnosti, čomu zodpovedá aj potreba zvýšenej pozornosti venovanej príčinám a podmienkam insolvenčných trestných činov. Verím, že tento vedecký článok je dobrým základom pre zvolenie správneho metodického postupu pri dokazovaní insolvenčných trestných činov v praxi.

\section{Literatúra:}

- KOLESÁR, J. 2010. Perspektívy dokazovania v trestnom konani s dôrazom na znalecké dokazovanie. Prievidza : Citicom, 2010.

- MADAR, Z. a kol. 1978. Právnický slovník. II. díl. P - Ž. Praha : Orbis, 1978.

- NEZKUSIL, J. a kol.1978. Československá kriminologie. Praha : Panorama, 1978.

- ŠAMKO, P. 2019. Trestné činy poškodzujúce veritelov. Bratislava : Wolters Kluwer, 2019.

- ŠÁMAL, P. a kol.2008. Trestní rád. Komentár̆ - díl I. 6. vydání. Praha : C. H. Beck, 2008.

- VIKTORYOVÁ, J. 2006. Dokazovanie. In Ivor, J. a kol.: Trestné právo procesné. Bratislava : IURA EDITION, 2006.

- TURAYOVÁ, Y. 2001. Kriminologické aspekty zločinu. Bratislava: IURAEDITION, 2001.

- R $14 / 1964$

- R 8/1985

- R 5/1988

- judikát Najvyššieho súdu ČR R 41/2002.

- rozsudok Najvyššieho súdu SR; sp. zn. 1 Tzo V/2005.

\section{Summary: Subject and scope of proving insolvency crimes}

The seriousness of insolvency offences should not be underestimated at all, as insolvency offences often lead to secondary insolvency, bankruptcies of self-employed and companies, rising unemployment and the overall economic decline of the country. In practice, criminal law enforcement authorities should pay more attention to the investigation of criminal complaints of suspected insolvency offenses and, if those suspicions are confirmed, to pay particular attention to the process of proving insolvency offenses, so that the offenses are reliably proven and their perpetrator justly punished and, secondly, in order to increase the general prevention of this crime, which corresponds to the need for increased attention paid to the causes and conditions of insolvency offenses.

doc. JUDr. Eduard Burda, PhD. Univerzita Komenského v Bratislave Právnická fakulta, Katedra trestného práva, kriminológie a kriminalistiky Šafárikovo námestie 6 81000 Bratislava Slovenská republika eduard.burda@flawuniba.sk 